\title{
Challenges and Teaching Strategies in Industrial Revolution 4.0 Era
}

\author{
Rezky Uspayanti \\ Universitas Musamus Merauke \\ Email:rezky05@unmus.ac.id
}

\begin{abstract}
This study aims to investigate the challenges and teaching strategies of English teachers in District Merauke. This study is a mix-method namely the combination of qualitative and quantitative methods. 16 English teachers as the participants in the study from six high schools in Merauke district namely Senior High School 1 Merauke, Senior High School 2 Merauke, Senior High School 3 Merauke, Vocational High School 3 Merauke, Senior High School YPK Merauke, and MA Al-Munawwaroh. Data collection instruments used were questionnaires and interviews. Questionnaires used consisted of 40 statements and the interview consisted of 14 questions related to challenges and strategy of teaching English in the era of industrial revolution 4.0. As a result, challenges in the teaching and learning process are, especially for online learning. Mostly the students are constrained in technology facilities and motivation of students. While for the strategy in teaching English in industrial revolution era 4.0, by motivating students about the importance of English, providing variations in learning such as the use of video, audio, practice variety questions, using the online application (WhatsApp, google classroom, google translate, zoom, and google meet. Besides, by using discussions, question and answer directly, blended learning method, discovery learning, using image media, audio Lingual Method, TPR, GT, using voice note. Thus, by merging cognitive, affective, and psychomotor processes. Besides, for strategies in creating interesting and creative learning in the era of industrial revolution 4.0, by using jokes, games, giving advice, giving praise, and collaborating with native speakers in online learning.
\end{abstract}

Keywords: Challenges, teaching strategies, English teachers, industrial revolution 4.0

\section{INTRODUCTION}

Education is crucial and universal that plays a role in the quality of human resources. Education makes human resources faster and ready in the face of change. The development of the education system can be a support in the progress of the nation. Education will always change and develop. The era of industrial revolution 4.0 can be seen by increasing the development of digital systems in education. This era is the advancement of science and technology which has an impact on educational zones. Industrial Revolution 4.0 occurred around the 2010 s through intelligence engineering and the internet of things as the base machine movement and connectivity (Prasetyo \& Trisyanti, 2019). (Lase, 2019) suggested that the change of era at this time is inevitable, 
therefore there needs to be adequate preparation of human resources to be able to compete.

In the era of industrial revolution 4.0, teachers are faced with more complicated challenges than in previous eras, where teachers encounter more varied students, more complex learning materials, and high standards in the learning process, so it takes teachers who can compete not only in terms of cleverness but creativity in creating effective teaching. Effective learning includes learning that is creative, interactive, educational, fun, and can achieve learning goals. The success in the teaching and learning process in the classroom depends on various factors, one of which is the language used by the teacher (Uspayanti, 2020), and also the strategy. Thus, to realize this, it is necessary to be precise in choosing learning strategies. Accuracy in strategy selection affects student learning achievement (Lutfiyati, 2018). Learning strategy is a general pattern of activities between teachers/lecturers and learners in realizing learning activities to achieve the learning objectives that have been set (Lutfiyati, 2018). There are several strategies in the teaching and learning process, namely teacher concentration strategies, student concentration strategies, material concentration strategies, and assignment-based (Ismail, A. M., \& Salleh, 2016). Furthermore, teachers are expected to have a good performance in pedagogy, professionalism, socialism, and personality (Nurchalis, 2020). Thus, teachers need to gain knowledge and skills by adapting to the latest innovations in teaching and learning proses to produce more skilled, talented, creative, innovative, and successful students to produce high-quality products that can compete in the globalization era (Ismail et al., 2020).
Industrial revolution term is connected to some basic changes that occur in the field of industry, starting from industry 1.0, 2.0, 3.0, to industry 4.0. The biggest challenge of the industrial revolution 4.0 is that this era will bring major changes to the structure, model, and type of work needed (Afrianto, 2018)internets of things, internet of people, big data, iCloud data, and artificial intelligence. All of these new developments have brought about disruption in various sectors of life, including education. The IR 4.0 can be negative, as it can threaten the existence of schools and teachers. Yet, it can also be positive because it brings many opportunities for innovative research and classroom practices which can subsequently accelerate and optimize teachers' productivity and students' learning outcomes. Therefore, professional teachers must be aware of and adapt themselves to this development. Teachers of this digital age, for instance, should be teachers with the 21 st-century learning mindset, possess digital literacy, keep learning new things, and should able to make use of opportunities provided by the IR 4.0 for their better teaching. Integrating classroom activities with some online platforms through blended/hybrid learning is a highly recommended teaching strategy for today's teachers. In short, if they are carried out consciously and systematically, all developments in the IR 4.0 will certainly have a positive impact on the achievement of our national education goals in the future.", "author":[[“droppingparticle":"”,"family":"Afrianto","given":",",nondropping-particle":",", parse-names":false,"suffix": "'\}]," container-title":"English Language Teaching and Research","id":"ITEM-1","issued":\{ “date-parts" :[“2018”]]\},"title":"Being a Professional Teacher in 
the Era of Industrial Revolution 4.0: Opportunities, Challenges and Strategies for Innovative Classroom Practices Afrianto Faculty of Teachers Training and Education (FKIP. Learning styles and best practices must also be filled with blended learning methods because this method is one of the learning solutions in the era of revolution 4.0 (Risdianto, 2019). Creative Education 4.0 ends innovation by focusing on improving education and skills to make future learning more personal, super, smart, portable, global, and virtual (Sharma, 2019). Education 4.0 promotes education differently, mainly by consuming technology-based tools and resources. Education 4.0 allows remote students to access the Internet and enroll in courses through a variety of open online courses, video chats, or voice calls to learn more dynamic material about the same students (Sharma, 2019). Industry 4.0 is a level of a technological revolution that can change the way human activities in the scope, complexity, scale, and transformation of previous life experiences (Yahya, 2018). In the era of industrial revolution 4.0, future generations should master not only one language but also more than one language. English is a foreign language that is used as a subject almost all over the world including Indonesia. Quoted from the German philosopher Johann Wolfgang Von in Handayani (Handayani, 2016), states that "Those who know nothing about foreign language, they are nothing about their own". It can be inferred that people should know more languages, especially the English language. teaching the English language is necessary for involving culture in the instructional activities.

Based on observations, students still tend to be passive in both classroom learning and online learning. In addition, the lack of motivation in English language learning resulted in the results of learning. Related to this, teachers are required to be able to innovate in teaching by providing the right learning methods / strategies that are in accordance with the needs of students. In addition, what is happening in Merauke today, in the classroom there are students with varying abilities, from which we as teachers, how to create innovative and fun teaching that will improve English language skills and cooperation in learning. In addition, at this time, the world is faced with the problem of Covid 19 which has caused several sectors to decline, including the economic and educational sectors. Based on the initial observations, the researchers conducted an analysis related to the Challenges and Teaching Strategies of English Teachers in the Era of Industrial Revolution 4.0.

The problem statements are the challenges of the teachers in teaching English in Merauke District and the strategy used by English teachers in teaching in the era of industrial revolution 4.0. The objectives aim to find out the challenges faced by teachers in teaching English in Merauke district and the effective strategies used by teachers in teaching English in the era of industrial revolution 4.0 that can be used as guidelines by other teachers on strategies that suit the needs of their students in Learning English.

\section{METHODS}

This study is a mix-method namely the combination of qualitative and quantitative methods. This research was conducted in several high schools in Merauke district that were sampled. The research was conducted from September to October 2020. 
Purposive sampling techniques are used to determine research samples. This is done by taking the subject not because it is based on strata, random or regional but based on the existence of a specific purpose.

In this study, the researchers choose six High School in District Merauke namely Senior High School 1 Merauke, Senior High School 2 Merauke, Senior High School 3 Merauke, Senior High School YPK Merauke, SMK 3 Merauke, and MA AlMunawwaroh. Those consisted 16 English teachers. Six high schools was chosen to see the variation for the challenges and teaching strategies, thus it also was chosen because some schools as superior in Merauke and the other still need attention or left behind. So, it can show the variation and can represent the other school in Merauke not only in challenges in teaching English but also the strategies.

Purposive sampling is a technique in determining samples based on certain considerations (Sugiyono, 2012). Instruments that had been used in the form of questionnaires and interviews. The questionnaire and interview created by own with pay attention on theory related to the tittle. It is also has been seen by some experts. The questionnaire contained 40 items consisting of 20 statements related to challenges in Teaching English and 20 statements related to strategies in Teaching English. The interview contained 14 questions, namely 7 questions related to challenges and 7 questions related to strategies in teaching English in the era of industrial revolution 4.0. Scoring scores for questionnaires using the Likert scale. The data obtained has been analyzed using simple statistical analysis to obtain percentages. The results of the analysis in the form of percentages are then processed qualitatively by descriptive data. An interview has been analyzed using qualitative analysis data based on Miles and Huberman theory (Miles \& Huberman, 2012) which consists of three stages, namely data reduction, display data, and conclusion verification. Then in the final stage, conclusions are made based on the results of the data analysis.

\section{FINDINGS AND DISCUSSION}

The data were obtained through questionnaires and interviews. Questionnaires consisted of 40 statements, 20 statements related to challenges in teaching, and 20 questionnaires related to strategies in teaching.

\section{Result of Questionnaire related to Challenges in Teaching English}

For the 20 statements related to challenges in teaching namely (1) In teaching English via online, most students are constrained in terms of technology facilities, (2) The condition of students in various aspects is very diverse, so the students are difficult to achieve learning objective especially for online learning in the era of industrial revolution 4.0, (3) I had difficulty in technology-based teaching due to lack of training, (4) Based on my observations, students' motivation in learning English both online and face-to-face is still low, (5) As teacher, I still have difficulty in arousing students' enthusiastic for asking and answering questions especially in online learning, (6) My ability to provide learning materials is still limited, (7) I as a teacher have personal technology facilities such as laptops, but still lack of knowledge about the functions of these communication tools and have not been able to apply maximum in 
teaching English, (8) (My) ability to involve students in learning is still low because students still do not understand the material, (9) I as a teacher is still difficult to use efficient time, as a result it can happen that the lesson material is finished, but the time is still long. Or vice versa, time is running out, the material is not yet complete, (10) Lack of IT skills and digital technology and still difficult to upgrade the knowledge, (11) Lack of equitable access to get quality education, (12) I find difficult to develop and teach new literacy (big data, technology/coding, humanities), (13) I have difficulty to implement Hybrid/Blended Learning \& Online teaching system, (14) I have difficulty to implement google classroom in teaching English, (15) The challenge of an educator is not stopping at the ability to apply technology information in teaching and learning process but has other skills, (16) Have supporting technology facilities in schools but still difficult to use and apply to the students, (17) I as a teacher have a poor understanding of the students' characteristics in the industrial $4.0 \mathrm{era}$, (18) In learning, as a teacher I give students the opportunity to make their own decisions about the subject matter they face, (19) Creativity in preparing materials is a challenge for me as a teacher, (20) Schools are still lacking in activities that support creativity and innovation of students with technology-based. The result of percentage can be seen in table 1 that $S T=$ Statement, $S A=$ Strongly Agree, $\mathrm{A}=$ Agree, $\mathrm{N}=$ Neutral, $\mathrm{DS}=$ Disagree,
$\mathrm{SD}=$ Strongly Disagree, NA $=$ Not Answer. The researchers uses 5-Likert scale based on suggestion from the some teacher based on trial, some of them, need neutral answer.

Table 1. The questionnaire percentage of Challenges in Teaching English

\begin{tabular}{|r|r|r|r|r|r|r|r|}
\hline Nu & ST & \multicolumn{1}{|c|}{ SA } & \multicolumn{1}{c|}{ A } & \multicolumn{1}{c|}{ N } & \multicolumn{1}{c|}{ DA } & \multicolumn{1}{c|}{ SD } & NA \\
\hline 1 & 1 & $25 \%$ & $56.25 \%$ & $12.5 \%$ & $6.25 \%$ & 0 & 0 \\
\hline 2 & 2 & $37.5 \%$ & $50 \%$ & 0 & $12.5 \%$ & 0 & 0 \\
\hline 3 & 3 & $6.25 \%$ & $12.5 \%$ & $25 \%$ & $43.75 \%$ & $12.5 \%$ & 0 \\
\hline 4 & 4 & $12.5 \%$ & $31.25 \%$ & $18.75 \%$ & $31.25 \%$ & $6.25 \%$ & 0 \\
\hline 5 & 5 & $18.75 \%$ & $31.25 \%$ & $12.5 \%$ & $31.25 \%$ & $6.25 \%$ & 0 \\
\hline 6 & 6 & $6.25 \%$ & $12.5 \%$ & $25 \%$ & $37.5 \%$ & $12.5 \%$ & $6.25 \%$ \\
\hline 7 & 7 & $6.25 \%$ & $25 \%$ & $18.75 \%$ & $37.5 \%$ & $12.5 \%$ & 0 \\
\hline 8 & 8 & $12.5 \%$ & $12.5 \%$ & $37.5 \%$ & $25 \%$ & $12.5 \%$ & 0 \\
\hline 9 & 9 & $6.25 \%$ & $18.75 \%$ & $25 \%$ & $37.5 \%$ & $12.5 \%$ & 0 \\
\hline 10 & 10 & $6.25 \%$ & $6.25 \%$ & $18.75 \%$ & $50 \%$ & $18.75 \%$ & 0 \\
\hline 11 & 11 & $18.75 \%$ & $18.75 \%$ & $25 \%$ & $25 \%$ & $6.25 \%$ & $6.25 \%$ \\
\hline 12 & 12 & 0 & $37.5 \%$ & $25 \%$ & $31.25 \%$ & $6.25 \%$ & 0 \\
\hline 13 & 13 & 0 & $18.75 \%$ & $50 \%$ & $31.25 \%$ & 0 & 0 \\
\hline 14 & 14 & 0 & $18.75 \%$ & $25 \%$ & $43.75 \%$ & $12.5 \%$ & 0 \\
\hline 15 & 15 & $37.5 \%$ & $50 \%$ & $12.5 \%$ & 0 & 0 & 0 \\
\hline 16 & 16 & 0 & $12.5 \%$ & $31.25 \%$ & $37.5 \%$ & $18.75 \%$ & 0 \\
\hline 17 & 17 & 0 & $12.5 \%$ & $37.5 \%$ & $31.25 \%$ & $18.75 \%$ & 0 \\
\hline 18 & 18 & 0 & $50 \%$ & $12.5 \%$ & $18.75 \%$ & $18.75 \%$ & 0 \\
\hline 19 & 19 & $25 \%$ & $62.5 \%$ & $12.5 \%$ & 0 & 0 & 0 \\
\hline 20 & 20 & 0 & $12.5 \%$ & $18.75 \%$ & $50 \%$ & $18.75 \%$ & 0 \\
\hline
\end{tabular}

Based on the table 1, it can be described for the first statement, there are $25 \%$ respondents strongly agree, $56.25 \%$ agree, $12.5 \%$ give a neutral answer, and $6.25 \%$ respondent disagrees. For the highest strongly agree responds can be seen for statement 2 and 15 . For the second statement, $37.5 \%$ of respondents 
strongly agree, $50 \%$ of respondents agree, and $12.5 \%$ of respondents disagree with that statement. For statement $15,37.5 \%$ of respondents strongly agree, $50 \%$ agree, $12.5 \%$ are neutral. Meanwhile, for the lowest percentage of strongly agree can be seen in the statement 3, 6, 7, 9 and 10 namely only $6.25 \%$ or one respondent strongly agree for the statement. Statement 4, 12.5\% of respondents strongly agree and $31.25 \%$ agree. Statement 5, $18.75 \%$ of respondents strongly agree and $31.25 \%$ of respondents agree. Statement $8,12.5 \%$ of respondents strongly agree, agree, and strongly disagree. Furthermore, statement $11,18.75 \%$ of respondents strongly agree and agree. For statement $12,37.5 \%$ of respondents agree. Statement 13 and $14,18.75 \%$ of respondents agree. Statement 16 and 17, 12.5\% of respondents agree. Statement $18,50 \%$ of respondents agree and $12.5 \%$ are neutral. Statement 19, 25\% strongly agree, $62.5 \%$ agree, and $12.5 \%$ are neutral. For the last statement, $12.5 \%$ agree and $50 \%$ disagree. For the detail result percentage, can be seen in the table 1 .

\section{Result of Questionnaire related to Strategies in Teaching English}

For 20 statements related to strategy in teaching English namely, (1) As a teacher, I can master and utilize digital technology in teaching English, (2) I know education in 4.0 era and am able to apply it in learning, (3) I communicate and interact effectively and efficiently with the students both in face to face and online teaching, (4) In teaching, I use learning source based on competencies developed, (5) In teaching, I implement learning, use technology as often as possible, and approach students, (6) One of the ways I use in teaching is to approach students and familiarize students with technology, (7) I as a teacher, have communication tools and know the functions of communication tools such as mobile phones, laptops, etc. and can apply it maximum in teaching English, (8) Provide an overview of the material to be taught so that students know the direction of the subject matter to be discussed, (9) At the end of the meeting, I concluded the material that had been described both online and face-to-face, (10) As a teacher, I can utilize technology facilities for searching more interesting teaching materials so the students are passionate about following learning and utilizing the sophistication of technology to support learning, (11) In teaching, I connect the material with reality daily life in both online and face to face teaching, (12) Generate students' activeness in every activity such as asking and answering questions both online and face-to-face, (13) In teaching, I use varied strategies and methods to make it easier for students to understand, (14) Using strategies based on students' needs, (15) In teaching, I provide personal habituation, implementation of learning, and understand the development of industry 4.0, (16) In teaching, sometimes I use grouping and discuss method, (17) In teaching, sometimes I use students centered method/strategy and teacher centered method/ strategy, (18) Blended learning system is as way for teaching in covid-19 pandemic, (19) Teachers must adjust the infrastructure of information technology learning, (20) The teaching media used must be in accordance with learning objectives and can respond to students learning both online and face-to-face in supporting competition 
in the era of industrial revolution 4.0. The result of percentage can be seen in table 2 that $S A=$ Strongly Agree, $\mathrm{A}=$ Agree, $\mathrm{N}=\mathrm{Neutral}, \mathrm{DS}=$ Disagree, $\mathrm{SD}=$ Strongly Disagree, NA = Not Answer.

Table 2. The questionnaire percentage related to strategy in teaching English

\begin{tabular}{|r|r|r|r|r|r|r|r|}
\hline Nu & ST & SA & A & NA & SD & NA \\
\hline 1 & 1 & $43.75 \%$ & $50 \%$ & $6.25 \%$ & 0 & 0 & 0 \\
\hline 2 & 2 & $25 \%$ & $50 \%$ & $18.75 \%$ & $6.25 \%$ & 0 & 0 \\
\hline 3 & 3 & $31.25 \%$ & $56.25 \%$ & $12.5 \%$ & 0 & 0 & 0 \\
\hline 4 & 4 & $43.75 \%$ & $43.75 \%$ & $6.25 \%$ & 0 & 0 & $6.25 \%$ \\
\hline 5 & 5 & $31.25 \%$ & $50 \%$ & $18.75 \%$ & 0 & 0 & 0 \\
\hline 6 & 6 & $37.5 \%$ & $50 \%$ & $12.5 \%$ & 0 & 0 & 0 \\
\hline 7 & 7 & $56.25 \%$ & $31.25 \%$ & $6.25 \%$ & 0 & 0 & $6.25 \%$ \\
\hline 8 & 8 & $68.75 \%$ & $31.25 \%$ & 0 & 0 & 0 & 0 \\
\hline 9 & 9 & $62.5 \%$ & $31.25 \%$ & $6.25 \%$ & 0 & 0 & 0 \\
\hline 10 & 10 & $43.75 \%$ & $56.25 \%$ & 0 & 0 & 0 & 0 \\
\hline 11 & 11 & $50 \%$ & $50 \%$ & 0 & 0 & 0 & 0 \\
\hline 12 & 12 & $37.5 \%$ & $62.5 \%$ & 0 & 0 & 0 & 0 \\
\hline 13 & 13 & $43.75 \%$ & $56.25 \%$ & 0 & 0 & 0 & 0 \\
\hline 14 & 14 & $25 \%$ & $56.25 \%$ & $12.5 \%$ & $6.25 \%$ & 0 & 0 \\
\hline 15 & 15 & $18.75 \%$ & $37.5 \%$ & $31.25 \%$ & $6.25 \%$ & 0 & $6.25 \%$ \\
\hline 16 & 16 & $25 \%$ & $62.5 \%$ & $12.5 \%$ & 0 & 0 & 0 \\
\hline 17 & 17 & $12.5 \%$ & $43.75 \%$ & $31.25 \%$ & $12.5 \%$ & 0 & 0 \\
\hline 18 & 18 & $12.5 \%$ & $56.25 \%$ & $31.25 \%$ & 0 & 0 & 0 \\
\hline 19 & 19 & $31.25 \%$ & $37.5 \%$ & $25 \%$ & $6.25 \%$ & 0 & 0 \\
\hline 20 & 20 & $31.25 \%$ & $56.25 \%$ & $12.5 \%$ & 0 & 0 & 0 \\
\hline
\end{tabular}

Based on the table above, it can be described for the first statement, there are $43.75 \%$ of respondents strongly agree, $50 \%$ agree, and $6.25 \%$ are neutral. For the highest percentage result can be seen in statement 8 namely $68.75 \%$ of respondents strongly agree and $31.25 \%$ agree and followed by statement
9, $62.5 \%$ of respondents strongly agree, $31.25 \%$ agree, and $6.25 \%$ are neutral. While, the lowest score percentage can be seen to the statement 17 and 18 . Statement $17,12.5 \%$ of respondents strongly agree and disagree, $43.75 \%$ agree, and $31.25 \%$ are neutral and statement $18,12.5 \%$ of respondents strongly agree, $56.25 \%$ agree, and $31.25 \%$ are neutral. Furthermore, the next statement namely second statement, $25 \%$ of respondents strongly agree and $50 \%$ agree. Statement 3, 31.25\% of respondents strongly agree and $56.25 \%$ agree. Statement 4, $43.75 \%$ of respondents strongly agree and agree. Statement 5, 31.25\% of respondents strongly agree and $50 \%$ of respondents agree. Statement $6,37.5 \%$ of respondents strongly agree and $50 \%$ agree. Statement 7, 56.25\% of respondents strongly agree and $31.25 \%$ agree for the statement. Thus, for statement $10,43.75 \%$ of respondents strongly agree and $56.25 \%$ agree. Statement $11,50 \%$ of respondents strongly agree and agree. Statement 12 , $37.5 \%$ of respondents strongly agree and $62.5 \%$ of respondents agree. Statement 13, 43.75\% of respondents strongly agree and $56.25 \%$ agree. Statement 14, 25\% of respondents strongly agree, and $56.25 \%$ agree. Statement 15, 18.75\% strongly agree and $37.5 \%$ agree. For the last statement, $31.25 \%$ of respondents strongly agree, $56.25 \%$ agree, and $12.5 \%$ of respondents are neutral. For the detail result percentage, can be seen in the table 2 .

\section{The result of the Interview Related to Challenges in Teaching English}

14 questions have been given to English teachers in six schools in Merauke district. 7 questions related to The challenges in teaching and 7 questions related 
to strategy in teaching English. The first step namely the challenges in teaching English which consisted of seven questions. For the first question namely the challenges in online teaching English, from the result of the interview, the challenges faced by students are technology facilities from the students. Thus, the teachers are difficult to know the students who have to understand the material or not. Online teaching is not maximal and needs more time, thus the students are less active in the teaching and learning process. Besides, some teachers are still unfamiliar with online teaching, and some are already used to getting previous training. Furthermore, challenges in teaching English face-to-face were constrained on the motivation of students, especially vocational school and students majoring in social sciences. For the third question for blended learning where the problem is for online learning. The difficulty is in students who do not have adequate networks and technology facilities. For the fourth question, "what are the constraints in using google classroom?'Based on the result of the interview, most teachers have used google classroom in online teaching, but the constraints of using google classroom in learning are only some students who participate, and most students do not understand the use of google classroom itself. The use of google classroom is also constrained in terms of memory and storage. Next question, "what are the obstacles faced in utilizing technology in teaching English?", Based on observation, the problem is the same because students are still constrained by technology facilities where there are those who do not have an android, laptop, or pulse data. For SMK and Senior High School 1 and 2 Merauke, almost all students already have these facilities and can use technology devices both google classroom and so on easily. Although the facilities are complete and there is a quota of learning from the government, but teachers still have difficulty because the process of preparing materials with the use of technology is quite time-consuming. For the challenges in getting students to use technology in learning namely students already understand the use of technology themselves but most of them when learning online, more use that technology to play games. The last question namely the challenges in teaching during covid-19, in online learning only some students are enthusiastic about participating. in learning during this pandemic most schools implement online learning, students are more difficult to understand the material.

\section{The result of the Interview Related to Strategy in Teaching English}

There are 7 questions related to strategies in Teaching English in the era of industrial revolution 4.0 that has been given to English teachers in Merauke district. The first question is "how to create the process of learning English in the era of industrial revolution 4.0", based on an interview, the result showed that by motivating students about the importance of English. Also, by providing variations in learning such as the use of video, audio, practice variety questions. Especially for Senior High School YPK Merauke which consisted of indigenous Papuan students mostly, where the teacher has a way of teaching English by merging cognitive, affective, and psychomotor processes where the focal point is psychomotor. In other words, teaching and educating indigenous Papuan students requires 
learning and playing methods. The second question is "how do you take advantage of technology in teaching English?", by using variations in teaching such as the use of video, as well as other teaching applications such as google classroom, the use of google translate, google meet, whatsapp group, uploading videos on youtube to make them more enthusiastic and give tasks varied. The third question, "methods used in teaching English both online and face-to-face". Based on the results of the interview, it can be concluded that the method used in learning is for Senior High School 3 Merauke, teachers usually use whatsapp group in online learning, for offline teachers usually use lectures, presentations, and discussions. The same thing also happens in other schools, namely for offline presentations or practice in front of other friends and also Question and answer directly, blended learning system, discovery learning, using video, etc. For SMAN 1 Merauke, for teachers 1 most use image media both in online and offline learning. For whatsapp, teachers use it in terms of information sharing. For teacher 2, use Audio Lingual Method, TPR, GT.

Next, for strategies in creating interesting and creative learning in the era of industrial revolution 4.0 , the strategy used by using jokes and games as done by teachers at Senior High School 3 Merauke. The same thing is also done by teachers at Vocational School 3 Merauke, namely by using games and memorizing. Also, teachers use variety strategies in teaching, for example speaking learning use video not only focused on dialogue practice. For listening, sometimes combined with songs. Thus, the use of discovery learning and the use of voice notes in checking the presence of students. In Senior
High School YPK, teaching strategies by applying online learning interactively and non-interactively, life skill materials as additional materials, learning that suits the interests and conditions of learners and assignments do not focus on grades but more on qualitative assessments that are motivating. Besides, the way motivating the students in learning English with the use of jokes, games, giving advice, videos with themselves then shared, the use of interesting strategies, giving praise for achievements in learning and collaborating with native speakers in online learning. Furthermore, the evaluation of each meeting where the learning of almost all teachers who are the subject of research provide, and evaluation at each meeting. The last question is "how to teach during covid-19", teaching more to online teaching using a variety of variations in teaching. Use of online applications such as google classroom, whatsapp, zoom, applications from google such as GC, GM, GD, GA to send material, use videos, listen to English songs on youtube.

\section{CONCLUSION}

Based on the questionnaire and interview, the challenges in teaching and learning process are for online learning. Mostly the students are constrained in technology facilities and also adequate networks. challenges in teaching English face-to-face were constrained on the motivation of students, especially vocational school and students majoring in social sciences. While for the strategy in teaching English in industrial revolution era 4.0 , by motivating students about the importance of English. Also, by providing variations in learning such as the use of video, audio, practice variety questions. Thus

\section{6}


by merging cognitive, affective, and psychomotor processes where the focal point is psychomotor. For method in teaching, teachers usually use whatsapp group in online learning, for offline teachers usually use lectures, presentations, and discussions, question and answer directly, discovery learning, using video, using image media, audio Lingual Method, TPR, GT, and blended learning system. (Uspayanti, Bawawa, Betaubun, Butarbutar, \& Leba, 2020) blended learning is the combination of face to face meeting and non-face to face meeting using online learning or web-based technology.

For strategies in creating interesting and creative learning in the era of industrial revolution 4.0, the strategy used by using jokes and games, use variety strategies in teaching, for example speaking learning use video not only focused on dialogue practice. For listening, sometimes combined with songs. Thus, the use of discovery learning and the use of voice notes in checking the presence of students. Thus, teaching strategies by applying online learning interactively and non-interactively, life skill materials as additional materials, learning that suits the interests and conditions of learners, and assignments do not focus on grades but more on qualitative assessments that are motivating. Besides, the way motivating the students in learning English with the use of jokes, games, giving advice, videos with themselves then shared, the use of interesting strategies, giving praise for achievements in learning and collaborating with native speakers in online learning. Furthermore, teaching during pandemic covid 19, focused to online learning use of online applications.
This research will provide information and implication for readers, teachers and future research. Regarding the challenges faced in teaching, it is as source for future researchers who want to know the challenges in teaching deeply, in not only teaching English but also teaching the other subjects. It also give information for teachers about the challenges in teaching. In addition to provide an overview of the strategies used in in teaching, so as giving an overview to teachers and future research about the teaching strategies used in the industrial revolution 4.0 that could be a guideline about strategies used in teaching both online and offline.

\section{REFERENCES}

Afrianto. (2018). Being a Professional Teacher in the Era of Industrial Revolution 4.0: Opportunities, Challenges and Strategies for Innovative Classroom Practices Afrianto Faculty of Teachers Training and Education (FKIP), Universita. English Language Teaching and Research.

Handayani, S. (2016). Pentingnya Kemampuan Berbahasa Inggris Sebagai Dalam Menyongsong Asean. Ikatan Sarjana Pendidikan Indonesia (ISPI) Jawa Tengah.

Ismail, A. M., \& Salleh, S. M. (2016). Strategi Pengajaran dan Pembelajaran Pendidikan Islam di Sekolah Menengah Daerah Besut, Terengganu. Universiti Pendidikan Sultan Idris, Malaysia.

Ismail, N. A., Wahid, N. A., Yusoff, A. S. M., Noradilah, Wahab, A., Rahim, B. H. A., ... Zakaria, R. (2020). The Challenges of Industrial Revolution (IR) 4.0 towards the Teacher's Self-Efficacy.

Lase, D. (2019). Pendidikan di Era Revolusi Industri 4.0. SUNDERMANN: Jurnal Ilmiah Teologi, Pendidikan, Sains, Humaniora Dan Kebudayaan. https://doi. org/10.36588/sundermann.v1i1.18

Lutfiyati, I. L. (2018). Strategi Pembelajaran Pondok Pesaantren dalam Menghadapi Tantangan Era 
Globalisasi (Studi Kasus di Pondok Pesantren AlMuntaha Kota Salatiga). IAIN Salatiga. Publish Thesis.

Miles, M. B., \& Huberman, M. A. (2012). Analisis Data Kualitatif: Buku Sumber Tentang Metode-Metode Baru. In Universitas Indonesia_UI Press.

Nurchalis, N. F. (2020). Demands of English teacher competencies: Input for curriculum development at the University. EnJourMe (English Journal of Merdeka): Culture, Language, and Teaching of English, 5(2). https://doi.org/10.26905/enjourme. v $5 \mathrm{i} 2.4971$

Prasetyo, B., \& Trisyanti, D. (2019). Prosiding SEMATEKSOS 3 "Strategi Pembangunan Nasional MenghadapiRevolusiIndustri 4.0" REVOLUSI INDUSTRI 4.0. Revolusi Industri 4.0 Dan Tantangan Perubahan Sosial.

Risdianto, E. (2019). analisis pendidikan indonesia di era revolusi industri 4.0. ResearchGate.

Sharma, P. (2019). Digital Revolution of Education 4.0. International Journal of Engineering and Advanced
Technology (IJEAT, 9(2). https://doi.org/DOI: 10.35940/ijeat.A1293.129219

Sugiyono. (2012). Metode Penelitian Kombinasi (Mixed Methods). Bandung: CV Alfabeta.

Uspayanti, R. (2020). Assertive and Expressive Speech Act Used by English Teachers and Its Implications. Journal of Linguistics and English Teaching Studies, 2(1), 39-51. https://doi.org/https://doi. org/10.46870/lets.v2i1.52

Uspayanti, R., Bawawa, M., Betaubun, M., Butarbutar, R., \& Leba, S. M. R. (2020). The Implementation of Blended Learning Method on Chemistry Students' Motivation in Learning English. https://doi. org/10.2991/assehr.k.201014.092

Yahya, M. (2018). Era Industri 4.0: Tantangan dan Peluang Perkembangan Pendidikan Kejuruan Indonesia. Orasi Ilmiah Professor Bidang Ilmu Pendidikan Kejuruan Universitas Neegeri Makassar. 